\title{
Urban Land Use Planning as a Tool of Enhancing Cultural Legitimacy on Climate Change: Case of Turkey
}

\author{
Mediha Burcu Silaydın Aydın \\ Department of City and Regional Planning, Dokuz Eylül University \\ DEÜ Mimarlık Fak., Şehir ve Bölge Planlama Bölümü, Tınaztepe Yerleşkesi \\ Doğuş Cad. No: 209 Buca-İzmir, Turkey
}

Tel: 90-232-301-84-70Ｅ-mail: burcu.silaydin@deu.edu.tr

Received: December 2, 2013 Accepted: December 16, 2013

doi:10.5296/emsd.v3i1.4652 URL: http://dx.doi.org/10.5296/emsd.v3i1.4652

\begin{abstract}
While the problem of climate change directly interests persons and communities, the efforts to enhance cultural legitimacy on the problem still remains unsolved in our day. In this study, land use planning is regarded as a means to be used for enhancing cultural legitimacy on climate change, because land use planning has two-fold implications: one in terms of leaving significant impacts upon climate change, and the other, with regard to scope of its activities that are of concern of persons and communities directly. For this reason, land use planning can be considered as a bridge between climate change and its cultural legitimacy. In order to achieve this, it becomes necessary to identify those social groups whose actions and daily activities are of particular importance for land use planning and climate change and the modes of relationships in between should further be defined. There are four groups associated with land use planning and climate change: municipalities, users, investors and land owners, and non-governmental organizations and professional chambers. Proposed suggestions for enhancing cultural legitimacy on climate change are formulated separately for these groups. These suggestions are elaborated in the case of Turkish legal mechanisms and the planning practice.
\end{abstract}

Keywords: Climate change, Cultural legitimacy, Urban land use planning, Environmental legislation

\section{Introduction}

Leaving adverse impacts in social, economic and cultural terms, climate change takes place among the most important ecological problems on global scale today. The most significant document relating to this problem has been the United Nations Framework Convention on 
Climate Change (thereafter UNFCCC) dated 1992. In order to tackle the problem, mitigation of greenhouse gas emissions is taken as the ultimate objective in this convention and 1997 Kyoto Protocol. This led to formulation of programmes on national policies, actions and measures with special focus on greenhouse gas mitigation strategies in national and regional levels. Technology-supported and energy-related mitigation alternatives are put on the agenda in order to achieve emission targets. However, those local communities having roles in creation of greenhouse gas emissions and are directly and adversely affected by the social, economic and environmental impacts of climate change are kept outside the scope of possible solutions. In our day, people may be aware of the problem of climate change, but they remain far behind seeing themselves as part of the causes, yet having the potential to contribute to its solutions. Daily living habits and preferences of households determine the amounts of energy use and consequently become one of the factors causing domestic greenhouse-gas emissions. Furthermore, socio-economic status of individuals (e.g., high-income groups live in large houses that relatively use greater amounts of energy) and the specific roles they play (individual as a social actor; for instance as a tourism businessman, industrialist etc.) are also determining the amount of their shares in greenhouse-gas emissions.

Within this framework, local communities should acknowledge that a problem exists in order to promote viability and ensure success of mitigation strategies. However, the existing policy documents and legislative mechanisms lack sufficient emphasis on the need. To overcome this problem, there is need for an interface and means to bring together local communities and the international and national legislation and political platforms. Focusing on mitigation strategies and housing developments, this paper suggests that urban land use plans can be utilized as a means to create the common grounds for bringing the two poles (the individual and the climate) together, where the functional role of land use planning is depicted as a potential basis.

It is a difficult task to enhance cultural legitimacy on climate change and have all sections in the community become a part of the solution, because nature in modern society is seen as a means to be used for the ends (particularly the economic ends). It indeed remains a challenge to avail those communities-individuals for re-gaining consciousness of nature and to search for ecological sensitiveness in their actions. At this point, instead of targeting at the entire society as a whole, identification of certain social groups being connected to the problem in different contexts and formulation of suggestions that primarily focus on these groups would be meaningful as the initial step. In this regard, the following part of the paper will scrutinize the challenges in enhancing cultural legitimacy on climate change. Following the identification of above-mentioned groups in the third part, the discussion will dwell upon what to do to enhance cultural legitimacy in context of the relationship between land use plans and these groups.

No matter how climate-sensitive, land use planning cannot be expected to enhance cultural legitimacy on climate change per se. The subject matter here is the potential of land use planning in creating the grounds to raise awareness of local communities and to ensure that they accept the issue as a problem, or, in other words, to let the social groups confront the problem directly. For this reason, there is need for additional adjustments. Considered as such, 
this paper proposes the following issues as part of these frameworks: The importance of urban planning in climate change must be recognized and emphasized in international, and especially, national regulations and policies; new legal tools must be developed by local governments for climate-friendly land use plans; and public participation must be encouraged to involve inhabitants in climate-sensitive land use planning. The scope of this paper take the climate change-related legal and political mechanisms and planning practice in Turkey as the case.

One supplementary goal of this study is to draw attention to lack of integration between land use planning and mitigation strategies, which occupy a crucial place in international and national law and policies on climate change. Even though the non-negligible impact of climatically-insensitive urban spatial development practices upon creation of greenhouse-gas emission is well-known, there still exists a substantial gap between land use planning and adjustments to climate change. The proposed recommendations of this study aim to have contributions in overcoming this gap. Establishment of this integration is of pivotal importance for rapidly developing countries, particularly in terms of population growth and urbanization/urban development processes.

Developing countries must be full-participants in the problem of climate change for they will be most heavily impacted by global warming, and the scale of their emissions is rapidly approaching parity with developed countries (Wheeler, 2009). A considerable part of greenhouse-gases are caused mainly by domestic energy uses and loss of carbon sinks due to urban development. In Turkey, the rate of urbanization, which was 52,9 percent in 1990, has risen to 62,7 percent in 2006 , while the number of buildings have increased by 78,6 percent in the period of 1990-2000. Housing within the sectoral distribution of overall energy consumption reached a share of 30 percent in 2004 (Ministry of Environment and Forestry, 2007). Given the ongoing development of spatial environments, a possible turn to proactive planning will present an opportunity to block the future greenhouse-gas emission. For this reason, urban land use planning especially in developing countries can be used as an effective tool for enhancing cultural legitimacy on climate change on the one hand, and preventing from future emissions on the other.

\section{Challenges against Enhancing Cultural Legitimacy on Climate Change}

The most significant challenge against enhancing cultural legitimacy on climate change is the gap between nature and the individuals constituting different groups in society, particularly the urban inhabitants. This indicates that the problem is of broader extent, not specific to any country, but covering the structure of the modern society. Contrary to the people living in rural settlements and engaged in agricultural activities, urban inhabitants are getting disconnected from nature due to their economic activities and living environments. In a context as such, the indispensable difference between the rural and urban settlements pertains to the fact that urban development involves much different socio-economic relations when compared to the rural (S1laydın, 2003). The process of spatial development based mainly on sectors such as housing, commerce, transportation etc. results in creation of such urban environments that leave people uninformed about the multi-dimensional advantages to be 
gained if lived harmoniously with nature. Turkey has gone through this process as well. In the process of urbanization and industrialization that has taken start in 1950s and accelerated in post-1980s in Turkey, the migration movements from rural settlements to cities caused the majority of national population be agglomerated in urban areas. In the course of this period, cities as an outcome of real estate developments have turned into rapidly growing concrete agglomerations. The underlying reason has been the intention to attain the greatest building density in the least amount of area provided, consequently leading to loss of all bonds between the society and nature.

This problem may be overcome by convincing people about the psychological, health-related and economic advantages of living in spatial environments that are harmonious with nature and climate. Creation of such living environments through land use planning will provide for wider acceptance of a local-social framework in solving ecological problems or accepting that natural values should be protected.

The second challenge pertains to resilience of interest groups that receive economic gains from urban development activities. Capital owners in construction sector (developers, entrepreneurs etc.) and land owners intend to keep their surplus-profits constantly high. For this reason, they demand for developing natural areas as new urban settlement areas. For instance, the construction sector in Turkey has grown by 17,5 percent during the last quarter of the year 2010 only (Gürlesel, 2011). No doubt that climatically-sensitive building activities can possibly not be as rapid, high-rise and dense as in the case of existing practices. This will inevitably lead to constant expectation of high returns from the existing dynamic structure against climate-friendly planning processes which certains groups will object to and exert pressure upon. In parallel with this, land use planning activities formulate spatial development decisions (boundaries, size, location and density of settlement areas) and define the codes of building (number of storeys, building density, building alignment etc.). It is not legal to have any construction activities outside urban spatial boundaries and out of the scope of determined codes. Thus, despite such great sanction power of urban land use plans, why does the existence of resilient groups have a challenging impact against cultural legitimacy? The answer to this problem manifests the third challenge at issue. The authority of making land use plans in Turkey is in the hands of municipalities as local government bodies. Since elected municipal bodies have vote concerns, they occasionally remain weak against urban development demands and pressures. The cities, coastal areas, forestry areas and urban environments in Turkey display plenty of scenes as such (See Figure 1). Consequently, the design and planning of cities do not conform to local climatic characteristics (leading to proliferation of buildings that do not benefit from renewable energy resources via, for instance, its orientation) leaving no sufficient amount of green areas to absorb the $\mathrm{CO}_{2}$ produced by urban activities (Aydın \& Çukur, 2009). 


\section{Macrothink}

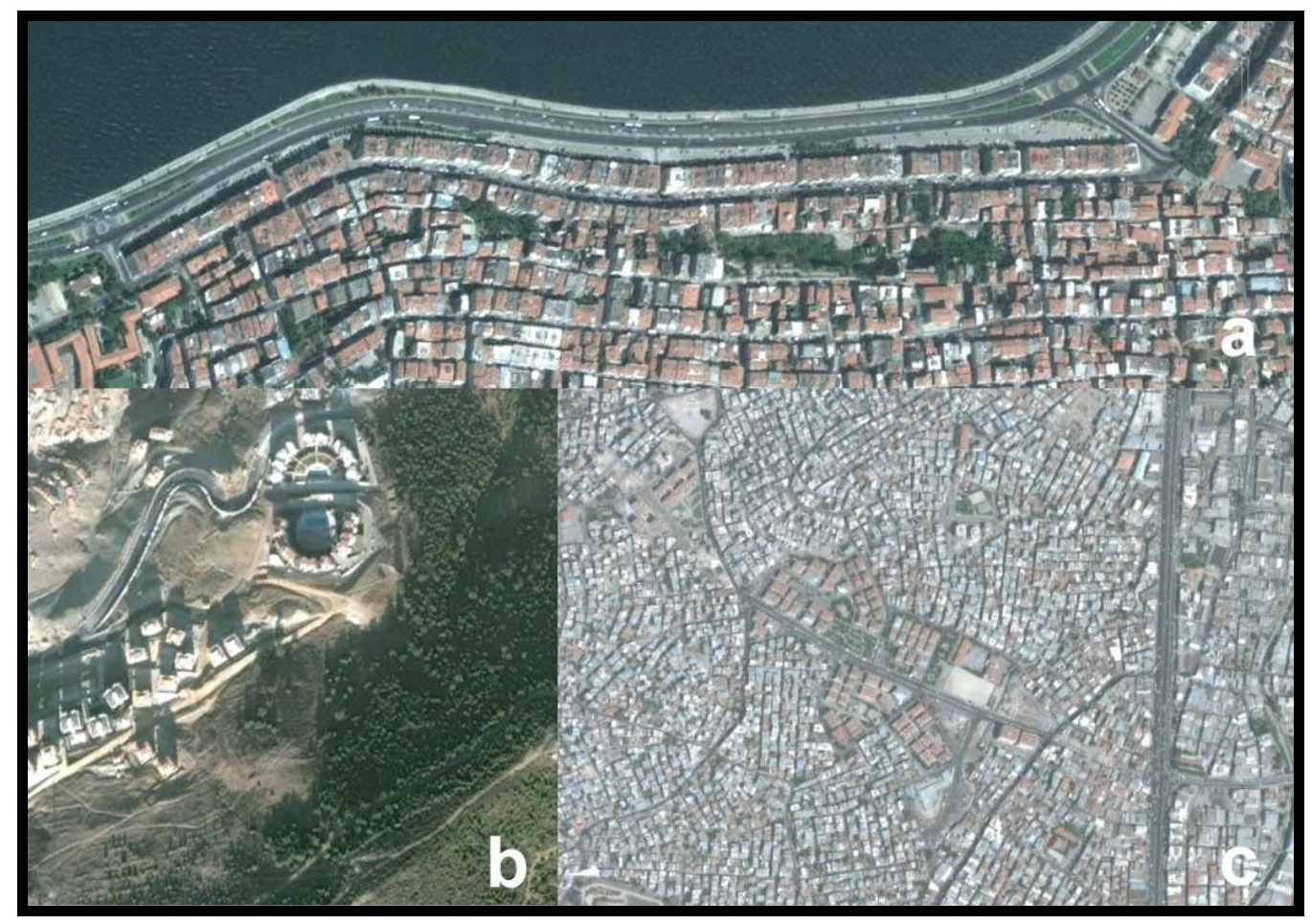

Figure 1. Urban Development Patterns in İzmir (Turkey).

a) Multi-storeyed buildings blocking the winds cooling the city

b) Pressure for urban development towards the carbon sinks surrounding the city

c) Residential areas devoid of green spaces

In international and national policy mechanisms, the facts that the relationship between climate change and public is based on mere education, training and public awareness and that there exists no specifically defined interface for public awareness in the local level, emerge, not as a challenge, but rather a problem to be overcome. The need for raising public awareness for climate change is already stated in the UNFCCC. The precautionary measures and suggestions focus on issues of education and training of public, scientific, technical and managerial personnel, and public awareness and participation in national, regional and sub-regional levels. These levels are beyond reach of local communities or inhabitants. In other words, no interface exists for the problem to be carried down to the local level.

Turkey has submitted its First National Communication to the United Nations Framework Convention on Climate Change in 2007. In the ninth part of this comprehensive report titled 'Education, training and public awareness', studies targeted at raising public awareness on climate change are presented. The Ministry of Environment and Urbanization taking the lead, the other related ministries and governmental bodies, higher education bodies, non-governmental organizations and some sections of the business world in Turkey carry out their works on public awareness and education on climate change. The steps taken include organization of seminars, conferences and workshops, inclusion of environmental issues in curriculum, training of technical personnel, short film and cartoon film screenings, public awareness and education activities for farmers, publication of various documents, and 
organization of campaigns as well as competitions (Ministry of Environment and Forestry, 2007).

Formulated as such, the current studies held in line with UNFCCC for public awareness on climate change in Turkey focus on public awareness, education and publicity activities. When climate change is considered in terms of enhancing cultural legitimacy, however, such approaches are not sufficient. The first reason behind this insufficiency is that these activities take place directly between the country and the individual, meaning that there exists no intermediary mechanism to bridge between local communities and national policies.

In provision of such an intermediary mechanism, local governments need to start playing a preponderant role, in which they should become an integrated part of those policies and action plans addressing to raising public awareness and acceptance of the problem regarding climate change. Empowerment of local governments as part of the solution is defended by the United Cities and Local Governments (thereafter UCLG). Yet, the existing convention documents on climate change are criticized for addressing inadequately to local and regional governments. In the United Nations Climate Change Summit held in Copenhagen in 2009, UCLG demanded the United Nations to accept the need for cooperation of local governments in international deliberations (UCLG-MEWA, 2013). The efforts of local governments to have their active involvement be accepted within the process are still brand new, which is why there yet could be no results attained out of international and national legal and political adjustments. Local governments hold the potential to be in close connection with local communities. Because of this, on the condition that local governments are reinforced to actively promote public awareness, their target groups will consequently grow further, expanding the extent of success.

In the First National Communication on Climate Change in Turkey, it is stated that local governments did not attempt to take their first step in public awareness on climate change yet (Ministry of Environment and Forestry, 2007). Departing from this point, the activities in priority must consist of taking precautionary measures to increase awareness of local governments to combat the problem of climate change, encouraging local governments for accomplishment of urban action plans, and through regulations, rendering local governments as legally responsible for taking the required local measures in solving the problem of climate change.

Studies and works on public awareness and education on climate change will undoubtedly have profound contributions for the local communities to accept the issue as a problem and take precautionary measures, but they remain insufficient to involve various interest groups. No matter how effectively public awareness is ensured, the above-explained challenges constitute an obstacle against local communities to adopt a climate-sensitive approach in their range of actions and daily activities. The acceptance level of the problem is dependent upon determination of the extent to which the interest areas of these groups directly come across the issue of climate change and formulation of those mechanisms which will guide them to accept the problem concerning these areas. Urban land use plans are drawn and written documents that embody this relation into spatial decisions. 


\section{Instrumental Significance of Urban Land Use Planning in Enhancing Cultural Legitimacy on Climate Change}

Land use planning in Turkey is carried on three plan scales: regional master planning, master planning and development planning. The power to make and approve master plans on scale 1/100.000 belongs to the Ministry of Environment and Urbanization. In terms of neither the authorized body nor the plan scale, regional master plans do not constitute a level requiring any relation with the local public. On local level, it is the master plans (on scales 1/25.000 or 1/5000) and development plans (on scale 1/1000) that function as plan levels significant for the subject matter at issue. Municipalities are responsible for making and approving these plans. According to the Municipal Law numbered 5393, municipalities can be established in settlement areas with population of 5,000 inhabitants and above. Pursuant to the Urban Development Law numbered 3194, it is mandatory for municipalities of settlements with populations above 10,000 in the most recent census to have development plans (urban land use plans) be prepared. Under these circumstances, urban land use plans in Turkey are prepared by greater municipalities, municipalities of provinces and districts and first tier municipalities of settlements with population above 10,000. If we are to define settlements having population above 10,000 as urban settlements, urban land use plans function as written and drawn documents of spatial decisions, which are of concern of the majority in the national population. These land use plans gain impetus for two main reasons within the objective framework of this study.

The first reason is that the rate of built to non-built environment (open green areas) within the urban space determines the rate of urban $\mathrm{CO}_{2}$ emissions to be absorbed by green areas. Decisions related to building activities in land use plans, on the other hand, such as terms and conditions of land use patterns, urban macroform, transportational infrastructure, building types and alignments, relationship between buildings and orientation of building blocks etc., have an impact upon use of urban vehicles and energy consumption in dwellings (see Condon et al., 2009). In brief, land use plans are directly related to mitigation strategies.

The second reason is that land use plans are of concern of the entire community living in the settlement. The level and ways of this concern vary by economic income levels of the inhabitants (as high, medium, low income groups), their fields of profession (those working in the commercial sector, businessmen, developers etc.), the role they play as actors in the city (public servants, non-governmental organization members etc.), and ownership of their properties (land and house owners or renters). Nevertheless, instead of taking local communities as an integrated whole in efforts for enhancing cultural legitimacy on climate change, it would rather be a more straight-forward approach to consider the issue on basis of different groups having varying roles regarding the problem.

Depicted as such, it is possible for us to ask the following question: which social groups and/or structures should the target group consist of in strategies to be fostered for enhancing cultural legitimacy on climate change via land use planning? The answer to this question will at the same time reveal how the instrumental character of land use planning may be utilized. 
Within this context, it is possible to identify four basic groups: 1) Municipalities, administered by representatives who are elected by the local public and hold the power to make land use plans, 2) capital owners who act as investors in the construction sector and land owners who try to receive economic gains from their real estate, 3) urban inhabitants whom can be defined as the user group, and 4) non-governmental organizations and relevant professional chambers who criticize implementations of the local governments.

There is no doubt that, apart from the above-listed groups, it is also possible to define more numbers of groups whose diverse range of activities have direct impacts upon climate change (e.g., factory owners, farmers who destroy forests in order to open land for their agricultural activities etc.), but since the core of this study focuses on land use planning and housing developments on urban scale, other irrelevant groups have been deliberately left out from the adopted scope of work.

\subsection{Municipalities}

Municipalities are included within the target group because they come into power through the elections, have the opportunity to represent local communities and for this very reason, are much more powerful in terms of guiding and orienting the local public on certain issues when compared to all other organizational bodies. Albeit they are managed by elected persons and political parties, municipalities are public institutions of the state, meaning that even though they attain a much liberal structure in implementation of their own policies, they cannot act independently from or opposing to national laws and regulations. This paves the way for mitigation strategies to be implemented on local scale, but the fact that municipalities are not authorized for tackling the problem via legal mechanisms hinders them from use of these grounds as an advantage.

In Turkey, the only power given to municipalities for combating climate change is concerned with reduction of energy use in buildings and transportation (particularly in city centres) and the increase in energy efficiency. As formulated in Table 1, liabilities of municipalities remain considerably limited with regard to precautionary measures on climatic change. Except for those displayed in Table 1, there exists no legal framework to encourage municipalities towards thinking on, producing policies for and taking precautionary measures against the problem of climatic change today. They are even not engaged in works for public awareness.

Table 1. Liabilities of municipalities on climate change in Turkish legislation

\begin{tabular}{|l|l|}
\hline \multicolumn{1}{|c|}{ Legislation } & \multicolumn{1}{c|}{ Liabilities } \\
\hline Regulation on & -Allocation of city gates to parking areas in site planning and \\
procedure and & urban regeneration projects; provision of methods to avail the \\
principles for & drivers for benefitting from mass transportation in their travels \\
increasing energy & to city centers \\
efficiency in & -Calming traffic at city centers via reduction of vehicles. \\
transportation & -Giving intermodal transportation system priority in mass \\
& $\begin{array}{l}\text { transportation stops. } \\
\text {-In mass transportation vehicles, if there exists a network, }\end{array}$ \\
\hline
\end{tabular}




\begin{tabular}{|c|c|}
\hline & $\begin{array}{l}\text { giving priority to vehicles with natural gas } \\
\text {-Minding fuel excavations in inner city transportation routes. } \\
\text {-Provision of bicycle roads and parking places where available }\end{array}$ \\
\hline $\begin{array}{l}\text { Regulation on } \\
\text { energy resources } \\
\text { and increasing } \\
\text { efficiency in } \\
\text { energy use }\end{array}$ & $\begin{array}{l}\text {-Provision of street lighting in conditions identified by the } \\
\text { regulation } \\
\text {-Being engaged in public awareness activities (this task is of } \\
\text { responsibility only of greater municipalities) } \\
\text {-Carrying out energy studies for use of thermal power station } \\
\text { heats in different sectors } \\
\text {-Giving priority to those districts where thermal power station } \\
\text { waste heats, if any, or central heating and cooling may take } \\
\text { place at mass housing estates to be newly-built and taking the } \\
\text { necessary precautionary measures for infrastructural planning } \\
\text { for distribution of heat. } \\
\text {-Estimation of the consumption figures for those buildings that } \\
\text { cover an area of ten thousand square meters and above in their } \\
\text { construction projects }\end{array}$ \\
\hline $\begin{array}{l}\text { Regulation on } \\
\text { energy } \\
\text { performance in } \\
\text { buildings }\end{array}$ & $\begin{array}{l}\text {-Provision of regulatory clauses on building energy efficiency } \\
\text { on architectural project design, heat insulation, heating and } \\
\text { cooling systems, ventilation and air conditioning systems, } \\
\text { lighting systems, and heated water preparation and distribution } \\
\text { systems. } \\
\text {-Control of application procedures, whether the buildings have } \\
\text { been constructed according to the conditions brought by the } \\
\text { regulation; giving construction permit to those buildings that } \\
\text { are duly constructed } \\
\text {-Appointing relevant persons to submit the heating insulation } \\
\text { projects of their buildings } \\
\text {-Preparation of reports on the required maintenance and tests } \\
\text { regarding efficiency } \\
\text {-Approval of energy identity documents prepared by authorized } \\
\text { organizational bodies. }\end{array}$ \\
\hline
\end{tabular}

Land use plans should be adopted as one of the most tangible means of implementation in order to guide municipalities towards addressing to the problem. Municipalities should be responsible to make such land use plans where the decisions on building activities are made on basis of reduction of these impacts or which prevent the problem prior to its emergence. This responsibility will carry the municipalities up to the position of taking an effective role for the solution, consequently leading to creation of circumstances where the problem of climate change is discussed together with local communities, whom they will inform on key measures for urban development activities.

In Turkey, the current mediation meetings on conservation plans present an example for such common ground where municipalities meet the local public on the issue of preservation. In 


\section{MInstitute Macrothink $_{\text {Int }}$}

2005, the "Regulation on Procedure and Principles Pertaining to the Preparation, Demonstration, Implementation, Control of Conservation Plans and Landscaping Projects and the Qualification of Persons Preparing the Plan" was enacted by the Ministry of Culture and Tourism. As stated in article 6, item $\mathrm{f}$ of the regulation, during the preparation process of conservation plans, it is mandatory to conduct two mediation meetings with participation of relevant professional chambers, non-governmental organizations, related departments of universities, workplace owners and households living within the conservation area and the involved inhabitants; one meeting for identification of problems, opportunities, vision, objectives, instruments and strategies prior to development of the plan decisions and the other meeting, after making of the plan, for the final review of the draft plan to be submitted to regional conservation council. These meetings gather local public with authorized representatives of municipalities together for consideration of conservation plans (See Figure 2).

Conservation plans are prepared for settlements located at valuable places distinctive for their natural and historical characteristics. In order to contribute in enchancing local acceptance of the problem of climate change, the practice of mediation meetings that are yet limited to specific areas should be allocated a more comprehensive scope to involve climate-friendly planning processes. Furthermore, these meetings will also provide for communication in explaining about the impact of climatic data-based building practice upon energy efficiency in housing areas and contributions to economic budgets of households.

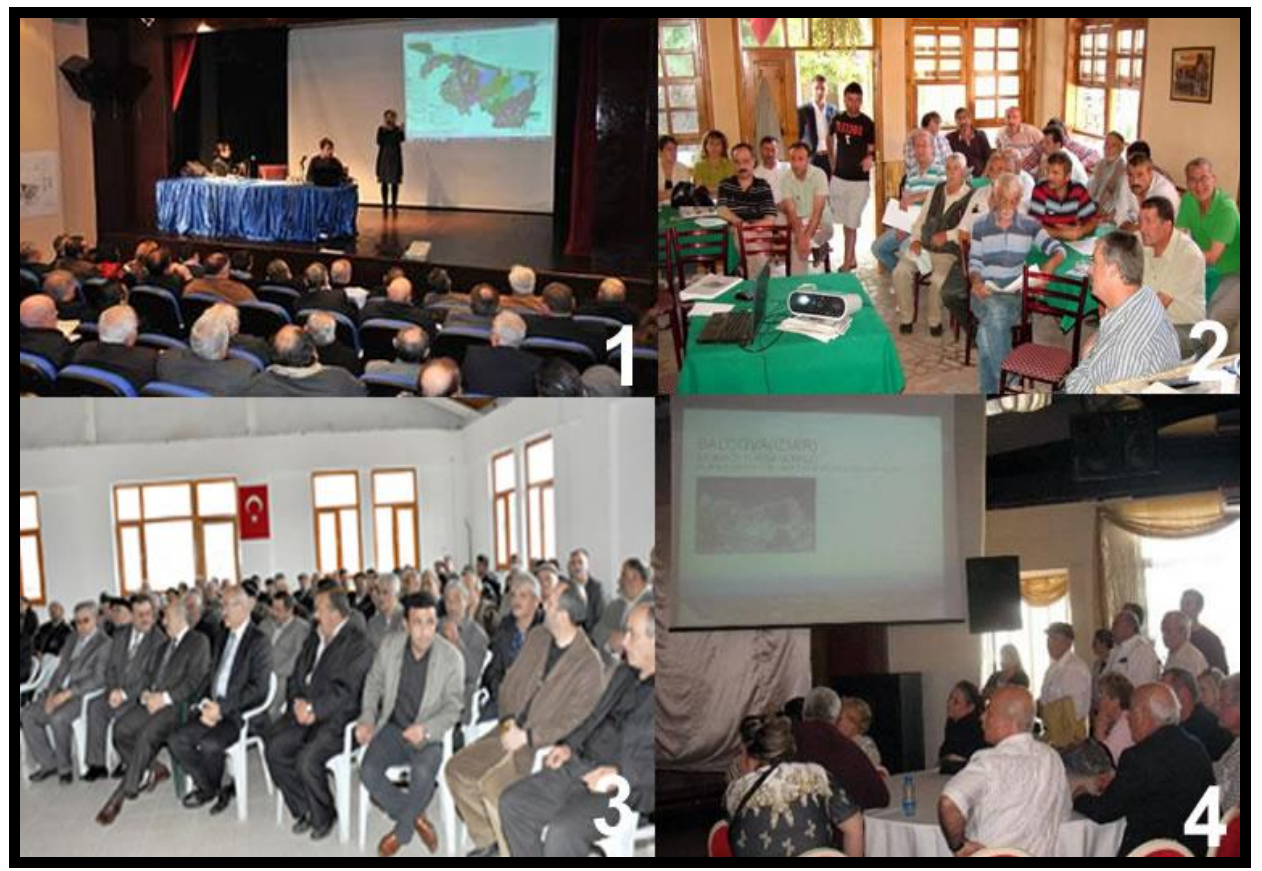

Figure 2. Mediation Meetings on Conservation Plans Held at Different Settlements.

1) Sarıyer (İstanbul) (Source: Kent Yaşam, 2011)

2) Gölcük (Kocaeli) (Source: Sarayl1-Örcün, 2010)

3) Yakaören (Isparta) (Source: Kanal 32, 2010)

4) Balçova (İzmir) (Source: Etki Haber, 2010) 


\subsection{Users}

This group consists of households residing at urban residential areas. Level of domestic energy use is dependent upon preferences of households (type and size of dwellings, type of energy used for heating, transportation preferences etc.) varying mainly by their economic income levels. The majority of domestic energy consumption leading to $\mathrm{CO}_{2}$ emissions is the result of their use of electricity and fuels spent for purposes of heating, cooling and lighting. Particularly the use of fossil fuels for heating purposes by low income households is the most important factor creating domestic greenhouse-gas emissions.

In the study held by Erickson et al. (2009) for six developing countries, the alternative solutions to reduce emissions caused by building activities in these countries are as follows: building codes and enforcement, appliance efficiency and labelling standards, retrofits of existing buildings via ESCOs, fuel switching from wood and oil to LPG and natural gas, new standards for lighting efficiency, more stringent building standards and mandatory efficiency targets (including use of solar hot water heaters), government R\&D for efficiency technologies and cost sharing for ESCOs. Likewise, the focus is on alternatives for technology-based solutions in Turkey. However, as in the case of Latin America discussed by Lankao (2007), solutions for increasing domestic energy efficiency through building insulation technologies bear challenges of application in developing countries having financial difficulties. Increasing energy efficiency in dwellings provide significant economic gains in the long term, but the initial set-up costs of these technology-based solutions are above household budgets of medium- and especially the low-income groups. Instead of targeting at long-term gains, households tend to refrain from short-term costs. Given these circumstances, especially in those countries where the gross national domestic product per capita remains low, merits of passive energy conservation gain more importance than technology-supported precautions for energy conservation in domestic uses, since they have direct contributions to household budgets. Land use plans are effective tools for passive energy conservation

\subsection{Investors and Land Owners}

Urban development demands of capital owners that exert pressure upon municipal governments are reflected on land use plans as decisions on building activities, which can be exemplified by proliferation of newly-developed residential areas, allocation of naturally-distinctive areas to tourism development areas, and transformation of urban waterfronts into housing areas consisting of attached, multi-storeyed buildings. Development of the built environment in such ways result in building densities that are not harmonious to local climatic conditions, further causing rise in amounts of energy use, on the one hand, and in reduction of carbon sinks due to changes in land use patterns, on the other.

As mentioned in the previous section, the investors and land owners will resist against spatial measures for reduction in climate change. Since they receive large amounts of economic gain from dense and rapid urbanization, it is very difficult for these groups to accept their responsibilities in the problem of climate change. For this reason, the existence of the problem of climate change should definitely be imposed upon this group. 


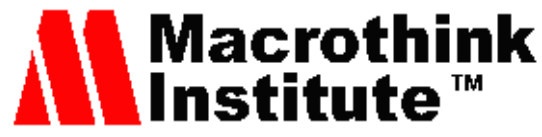

Given this, land use plans may be used as an imposing power on the issue. In order to succeed, the existing framework of planning practice should differ considerably. In Turkey, the housing development areas and building codes are given in the master and development plans. Land use planning measures, which are binding for developers, terminate after completion of the construction phase. There may be two different solutions in guiding the investors towards addressing the issue of climate change. Firstly, if land use plans are prepared harmoniously to local climatic conditions where building codes are based on provision of passive energy gains, then developers will have to execute their construction activities paying the greatest caution. This imperative, independent from their own preferences, will function as a means to encourage the investors to accept their responsibility in the problem of climate change. The investors and land owners are, in fact, in a position that is rather passive here. With the intention to alter their position from passive to active, the second solution involves fostering such regulations where these groups may make use of a part of their gains from building activities for possible solutions targeted at climate change. No matter how sensitive the building activities are, construction of a new building inevitably entails $\mathrm{CO}_{2}$ emission. Thus, investors may be asked to compensate for the problem via making payments for such services as support (forestation) of inner-city green areas and its environs or payments for environment taxes (at rate of their construction).

\subsection{Non-governmental Organizations and Professional Chambers}

Non-governmental organizations and professional chambers are organizational bodies that operate on a volunteering basis. Among the four groups listed, these bodies are the ones most sensitively approaching to environmental problems in comparison, but it still is difficult to state that they are actively engaged in any framework on climate change in Turkey. Nevertheless, this group is the one mostly inclined towards accepting the problem. The current works and studies held by these groups are confined to public awareness and miscellaneous activities. Land use planning can be utilized as a means for achieving more concrete results out of their studies in order to let them function in a mechanism having control over local governments.

Plans prepared by municipalities are displayed for duration of one month for public review and appeal prior to their approval. During this process of public review and appeal, critiques and objectives against the entire plan are usually uttered by these groups. The Chamber of City Planners and the Chamber of Architects, both affiliated to the Union of Chambers of Turkish Engineers and Architects, can be named as the most actively engaged two professional bodies, which undertake an outstanding task in the very same context.

With regard to preservation of natural values, a considerable part of plan appeals dwells upon critiques of spatial development decisions leaving adverse impacts over natural areas (e.g., urban development decisions threatening water basins; transportation decisions putting pressure on urbanization of agricultural lands etc.). Preservation of natural areas is used as a substantial reference point in the course of plan appeals. Likewise, a wide range of evaluative remarks and critiques on climate change can also be offered for due considerations during the appeal. Until recently however, this problem failed to be duly evaluated. 
With the intention to clarify the issue further, the highly disputed transportation projects can be given as an example. If a plan gives place to any highway that will result in loss of substantial part of the natural environment, then this decision is criticized on basis of the loss at issue. When considered in terms of the climate change problem, this decision for a highway can, at the same time, be criticized for being a factor that causes an increase in use of motor vehicles, and in return, a rise in greenhouse-gas emissions. As stated afore, however, the problem of climate change is not addressed by these groups on basis of any critiques. Making climate-friendly land use plans or raising awareness of these groups will ensure that these groups may take an active role in creating solution via the appeal mechanism.

\section{Conclusion: Guiding and supporting legal tools}

It is a difficult task to enhance cultural legitimacy on the problem of climate change. In order to tackle this challenge, the intersecting ways of how the urban actors, various interest groups or individuals may address to the issue should be identified so that efforts to enhance cultural legitimacy may be executed duly. In this study, urban land use planning is depicted as one of these grounds where the mentioned actors come across the problem. The specific suggestions question how such a ground may be operationalized in line with the adopted objective framework.

The target of having established the above-demonstrated suggestions is dependent upon preparation of climate-friendly land use plans that aim at reduction of greenhouse-gas emissions. This study focuses on urban spatial development (the urban scale) only. Other studies should not be confined to scale of the city, but attain an approach minding the problem of climate change in spatial planning decisions of all scales and all types. The process of modern urban development and the means of its management and implementation embody efforts to reach spatial targets of economic development and solve the emerging economic and social problems. In recent times, primary objectives in spatial planning still lack any proactive framework that seeks for solutions against either existing or possible ecological problems. Even though land use planning bears profound impact upon climate change, it is quite rare for mitigation strategies to get integrated with urban land use planning activities. This course of spatial development minding ecological problems, in general and climate change, in particular, can be achieved through a major shift in the approach of land use planning.

Discussions on the problem of climate change are held on international and national political and legal grounds in search of possible solutions, but they do not focus much on precautionary measures in context of spatial planning yet. International treaties and conventions determine the overall objective framework in solving the problem. It is not any task of international legislative and political regulations to determine the methods of how (through which instruments or mechanisms) these objectives will be achieved on local level. Though not in detail, this task initially pertains to works and studies held on national levels. For this reason, the first step to be taken is that the role of urban spatial planning in climate change and its place within range of precautionary measures should be recognized and emphasized in all frameworks (national declarations, strategy plans, action plans and 
measures programmes etc.) on national scale. Given this, land use planning is to pave the way for the grounds required for revision of relevant legislative regulations that are guiding in planning implementations on national, regional, and local scales. These legislative regulations must address to liabilities of municipalities in order to ensure making climate-friendly land use plans and encourage public participation during the course of preparing plans.

In Turkey, the Urbanization Council has been organized by the Ministry of Public Works and Settlement in 2009. Under shelter of this council, a working group on 'Climate change, natural resources, ecological balance, and energy efficiency' was established consisting of a wide range of academics who have been actively engaged in studies that were finalized in a comprehensive report. In the report, the main weaknesses are associated with the problem that neither the development plans, nor the existing buildings are harmonious to micro-climatic conditions, since this subject matter is not given any place of priority on the agenda. This leads to the suggestion that planning for energy requirements should also accompany the accomplishment of site plans, altogether corresponding to a paradigm shift in urban planning (Ministry of Public Works and Settlement, 2009). This report proves a pleasing development for Turkey in terms of associating urbanization with climate change. The proposed suggestions are in need to be executed as rapidly as possible.

The most crucial support on political and legislative levels is received from suggestions proposed in academic studies. These studies must provide for an answer to the question of how climate-friendly land use planning can be carried out. However, it is rather rare even in academic studies to expound upon the measures to be holistically taken in any land use plan. The majority of literature on mitigation of greenhouse-gas emissions focuses on increasing energy efficiency in buildings (e.g. Hunt, 2004; Brown \& Southworth, 2008), compact city form and mixed-use development (e.g. Reginster \& Rounsevell, 2006; Brown \& Southworth, 2008), and reduction of emissions from vehicles through transportational means (e.g. Stone, 2003; Hunt, 2006; Reckien et al. 2007). Instead of those considerations that provide support on very specific issues, academic studies may be expected to foster more comprehensive and innovative suggestions to bring a shift in land use planning approach.

Studies of Zhang et al. (2007), Uy \& Nakagoshi (2008) and Aydin \& Çukur (2012) are the three examples that best encounters such a context. They search for a balance between $\mathrm{CO}_{2}$ emissions with production of $\mathrm{O}_{2}$ in urban environments, while estimating the amount of area to be allocated to green facilities as required by such a balancing approach in urban planning. There is need for such type of scientific approaches, methods and suggestions, which ensure that land use plans gain a climate-friendly quality in spatial organization of urban development and the determination of specific conditions. On the other hand, land use planning must be deprived of its economic development-based structure and embrace a brand new structure that is intertwined with the natural environment. In other words, suggestions of land use planning for combating climate change, in particular, and preservation of nature, in general, must not be confined to mere revisions, but be theoretically reinforced by discussions and proposals to the point, altogether paving the way for a shift in logic of land use planning. 


\section{Macrothink}

Environmental Management and Sustainable Development

ISSN 2164-7682 2014, Vol. 3, No. 1

\section{References}

Aydın, M.B.S., \& Çukur, D. (2009). Present Approaches for Solving of the Problem Climate Change and a Proposal Based on Protection of the Carbon Cycle. Paper presented at the International Ecological Architecture and Planning Symposium. Antalya. October.

Aydin, M.B.S. \& Çukur, D. (2012). Maintaining the carbon-oxygen balance in residential areas: A method proposal for land use planning. Urban Forestry \&Urban Greening, 11, 87-94. http://dx.doi.org/10.1016/j.ufug.2011.09.008

Brown, M.A., \& Southworth, F. (2008). Mitigating climate change through green buildings and smart growth, Environment and Planning A, 40, 653-675. http://dx.doi.org/10.1068/a38419

Condon, P.M., Cavens, D., \& Miller, N. (2009). Urban Planning Tools for Climate Change Mitigation Policy Focus Report, Cambridge USA: Lincoln Institue of Land Policy.

Erickson, P., Heaps, C., \& Lazarus, M. (2009). Greenhouse Gas Mitigation in Developing Countries Promising Options in China, Mexico, India, Brazil, South Africa and South Korea Working Paper, WP-US-0903, Stockholm Environment Institute.

Etki Haber, (2010). İnciraltı 2011'den sonra termal turizm merkezi olacak!. Available: http://www.etkihaber.com/inciralti-2011den-sonra-termal-turizm-merkezi-olacak-32942h.htm (accessed 09 May 2010).

Gürlesel, C.F. (2011). Türkiye ve Dünya Gayrimenkul Sektör Raporu 4. Çeyrek 2010 İstanbul: Gayri Menkul Yatırım Ortaklığı Derneği.

Hunt, J. (2004). How can cities mitigate and adapt to climate change?, Building Research and Information, 32(1), 55-57. http://dx.doi.org/10.1080/0961321032000150449

Kanal 32, (2010). Koruma amaçlı imar planı. Avaliable: http://www.kanal32.com.tr/HaberlerDetay.aspx?hid=1265 ( accessed 12 December 2010).

Kent Yaşam, (2011). Sarıer'de çok sesli imar planı toplantısı. Avaliable: http://www.extrahaber.com/haber.php?haber_id=14789 (accessed 21 February 2011).

Knoflacher, H. (2006). A new way to organize parking: the key to a successful sustainable transport system for the future, Environment and Urbanization, 18, 387-400. http://dx.doi.org/10.1177/0956247806069621

Lankao, P. R. (2007). Are we missing the point? Particularities of urbanization, sustainability and carbon emisssions in Latin American cities, Environment and Urbanization, 19(1), 159-175. http://dx.doi.org/10.1177/0956247807076915

Ministry of Environment and Forestry. (2007). Birleşmiş Milletler İklim Değişikliği Çerçeve Sözleşmesi Kapsamında İklim Değişikliği Birinci Ulusal Bildirimi (Ankara: Çevre ve Orman Bakanlığı).

Ministry of Public Works and Settlement. (2009). İklim Değişikliği, Doğal Kaynaklar, 


\section{I Macrothink}

Environmental Management and Sustainable Development

ISSN 2164-7682

Ekolojik Denge, Enerji Verimliliği ve Kentleşme Komisyonu Raporu (Ankara: Bayındırlık ve İskan Bakanlığg1).

Reckien, D., Ewald, M., Edenhofer, O., \& Lüdeke, M.K.B. (2007). What parameters influence the spatial variations in $\mathrm{CO} 2$ emissions from road traffic in Berlin? Implications for urban planning to reduce anthropogenic CO2 emissions, Urban Studies, 44(2), 339-355. http://dx.doi.org/10.1080/00420980601136588

Reginster, I., \& Rounsevell, M. (2006). Scenarios of future urban land use in Europe, Environment and Planning B: Planning and Design, 33, 619-636. http://dx.doi.org/10.1068/b31079

Sarayl1-Örcün. (2010). Saraylı köyünde imar bilgilendirme toplantısı. Avaliable:http://orcunsarayli.blogspot.com/2010/10/sarayl-koyunde-imar-bilgilendirme.html (accessed 07 October 2010).

Sılaydın, M. B. (2003). Fiziksel planlama, toplumsal bilinç ve ekoloji, Planlama, 2003(1), 9-13.

Stone, Jr., B. (2003) Air quality by design: harnessing the clean air act to manage metropolitan growth. Journal of Planning Education and Research, 23, 177-190. http://dx.doi.org/10.1177/0739456X03258634

UCLG-MEWA. (2013). BM iklim değişikliği zirvesi. Available: http://www.uclg-mewa.org/bm-iklim-degisikligi-zirvesi (accessed 27 October 2013).

Uy, P.D., \& Nakagoshi, N. (2008). Application of land suitability analysis and landscape ecology to urban greenspace planning in Hanoi, Vietnam. Urban Forestry \& Urban Greening, 7, 25-40. http://dx.doi.org/10.1016/j.ufug.2007.09.002

Wheeler, D. (2009). Greenhouse Emissions and Climate Change: Implications for Developing Countries and Public Policy Working Paper No.62., Washington DC: Commission on Growth and Development, The International Bank for Reconstruction and Development/The World Bank.

Zhang, L., Liu, Q., Hall, N.W., \& Fu, Z. (2007) An environmental accounting framework applied to green space ecosystem planning for small towns in China as a case study, Ecolojical Economics, 60, 533-542. http://dx.doi.org/10.1016/j.ecolecon.2006.07.022

\section{Copyright Disclaimer}

Copyright reserved by the author(s).

This article is an open-access article distributed under the terms and conditions of the Creative Commons Attribution license (http://creativecommons.org/licenses/by/3.0/). 